\title{
ANALYSIS OF THE LEVEL OF VULNERABILITY TO FLOODS USING THE METHOD OF SIMPLE MOVING AVERAGE (A CASE STUDY OF THE CITY OF PADANG)
}

Shary Armonitha Lusinia, Nugraha Rahmansyah

Universitas Putra Indonesia "YPTK", Padang

Shary21armansyah@upiyptk.ac.id, nugraharahmansyah@upiyptk.ac.id

\begin{abstract}
Flood is the overflow of the river flow due to water exceed the storage capacity of the river, so that overflow and inundate the plains or the lower regions in the vicinity. Floods are natural disasters that often occur in Indonesia because it is located in the tropics. A lot of flood prone areas which have high population density, due to less understanding of the community regarding the geographic region. Floods often occur in the City of Padang caused by high rainfall in the upstream areas of the river and the topography is hilly so increase the speed of the flow of water to the lower plains. In this study, the author examines the factors of vulnerability to flood by using the method of Simple Moving Average with a parameter of the flood that used rainfall and long rainy days.
\end{abstract}

Keywords : Flood, Kota Padang, Simple Moving Average

\section{Introduction}

Indonesia is a country prone to catastrophic flooding due to the layout, form, and the uniqueness of the weather. Muhi (2011) mention a variety of literature including the Intergovermental Panel On Climate Change (IPCC) concludes that increasing greenhouse gas concentrations lead to increased global warming resulting in global climate change. Climate change characterized by rising temperature and precipitation result in disaster (Akram, 2012). Indonesia is the country's third-biggest producer of greenhouse gases (Measey, 2010). Climate change significantly exacerbates the occurrence of extreme weather and flooding (Kwari et al., 2015) as well as the danger of flash floods (Wahid, 2016); (Morita, 2014); (Emam, 2016). The frequency and intensity of flooding in watersheds has increased in recent years especially in estuary areas with marginal lowlands (Rilo, 2013). The coastal area is strongly influenced by climate change because of sea level rise (Measey, 2010).

Rainfall exceeded the average rainfall led to some regions close to the river and beach in the City of Padang potentially flood. Ghozali (2015) stated the increase in population and urban growth have made the conversion of open space which can lead to flooding. Land use change of forestry with agriculture or even settlements as a result will change the ecosystem of the environment and cause damage to the environmental elements that trigger erosion and degradation of water flow and quality, while modification of land use lead to changes in aspects of social, economic, and cultural (Iskandar, 2015). Changes in spatial or land use more influence or contribution to flooding compared with the construction of physical flood control (Rosyidie, 2013).

According to the existing data on the BPS office of Padang City, almost every year the precipitation is in the City of Padang high and cause a flood. Flood is one of the aspects that are feared by society and the government City of Padang. The fears of the people and the government of the Padang City will be the occurrence of flooding based on the geographical 
location of the City of Padang which has a height of the surface of the soil that entered the category of flood-prone areas because the City of Padang is an area with the lowlands. The losses caused by the flood, especially the indirect losses, may be ranked first or second after the earthquake or tsunami. With the flood make the industrial and agricultural sectors that play an important role in advancing the quality of the economic society of the City of Padang to be decreased. Considering the sector to be the sector is important in improving the quality of the economic society of the City of Padang is in the industrial sector and the agricultural sector. The industrial sector will be hampered by the flood because the industrial sector depends the guy that infrastructure is not compromised. While the agricultural sector will feel the impact of the occurrence of flooding in the City of Padang considering the smoothness of the agricultural sector depends of the weather conditions and the condition of the premises. In an effort to anticipate flood in Padang City, the need for a study on vulnerability to flooding.

\section{Theoretical Basis}

\subsection{Decision Support System}

Decision Support system or Decision Support System (DSS) is an information system interaktif0 that provides information, modeling, and manipulation of data. The system was used to help make decisions in situations that are semistructured and situations that are not structured, where nobody knows for sure how the decision should be made (Alter, 2002).

Decision Support System (DSS) is usually built to support solution of a problem or to evaluate an opportunity. DSS is such that the application of DSS. Application DSS used in decision making. Application of DSS using the CBIS (Computer Based Information System) that is flexible, interactive, and can be adapted, developed to support the solution to the problem of specific management that is not structured.

Application of DSS uses data, provides easy user interface, and can combine the thinking of decision-makers. The DSS is intended to support management in doing the work that is analytical in situations that are less structured and the criteria are less clear (Kusrini, 2007).

\subsection{Simple Moving Average (SMA)}

Sma method is a method of forecasting done by taking skelompopk observation value, looking for the average as a forecast for the period to come. With the following formula (Sahu \& Kumar, 2014)

Where :

$$
F_{t+1}=\left(Y_{t}+Y_{t+1}+Y_{t+2}+\cdots+Y_{t+n+1}\right) / n
$$

$F_{t}=$ Forecast value for next perioda

$Y_{t}=$ The actual value at period $t$

$n=$ Limit number of the moving average

\section{Methodology}

In analyzing the data, we should think of stages or working steps. In this case, the author describes the several stages in analyzing the data that can be seen in the image below which is a research framework. 


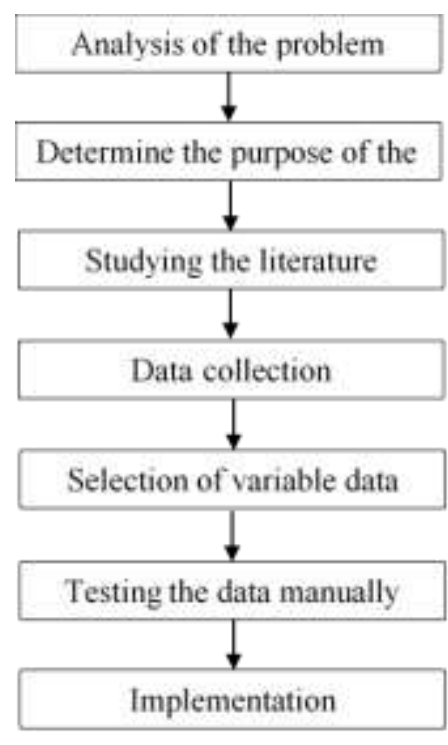

Image 1. Research Framework

The picture above is a reference to the author as the framework in analyzing the data.

1) Analysis Of The Problem

Before we do research, we first determine the problem level of the economy of coastal communities in Behalf Lakitan.

2) Determine The Purpose Of The Research

Before we do research, we need to determine to what research is done, and what is the purpose of this study, so that we can know the benefits of the research that we do.

3) Studying The Literature

To know the steps and techniques used in analyzing this research, we look for sources of knowledge related to the research that we will do, either in the form of journals, seminars, national and international, books and so forth.

4) Data Collection

In the collection of this data, used some of the methods that support, among others

a) Interview that performing a search to obtain data and information through question and answer and interviews with the people who berkopenten to the problems studied.

b) The Literature study namely data collection and information search by reading and studying the books and journals of related research and support, good in analyzing data and information and solving problems overall.

5) Selection Of Variable Data

After we do the analysis of the problem, next we must specify the variable input data. In the AHP method will be done the selection of attributes that will be used as criteria and alternatives. The criteria used are income, pengluaran, occupation, number of dependents/person, the status of home ownership, agricultural production, livestock production and other land assets, housing conditions, and other assets. Variables that serve as the alternative is a society that will meneriba help.

6) Testing The Data Manually 
Testing this data describes factors or model data connectivity to coastal communities by using the AHP method.

7) Implementation Using Software

In analyzing this data the researcher used a WEB-based application that also as one of the expected outcomes.

4. Results and Discussion

In the decision support system for prediction of level of vulnerability to flood in the City of Padang has the ability to help determine or predict the level of vulnerability to flood. As for the measures in the prediction of rainfall and land use with the method of Simple Moving Avarage (SMA) is as follows

Table 1. Rainfall Data For The City Of Padang

\begin{tabular}{rrrrrrrrrrrrrr}
\hline \multirow{2}{*}{ Year } & \multicolumn{10}{c}{ Amount Of Rainfall $\left(\mathrm{mm}^{3}\right)$} \\
\cline { 2 - 14 } & \multicolumn{1}{c}{ Jan } & Feb & \multicolumn{1}{c}{ Mar } & \multicolumn{1}{c}{ Apr } & \multicolumn{1}{c}{ Mei } & Jun & Jul & Agus & Sept & Okt & Nov & Dec \\
\hline 2011 & 264.8 & 426.8 & 815 & 233.7 & 280.7 & 346.2 & 372.3 & 308.8 & 539.2 & 602.2 & 580 & 205.9 \\
2012 & 156 & 240.1 & 219.5 & 327.1 & 73.1 & 420.2 & 199.5 & 113.8 & 266.7 & 238.2 & 895 & 329 \\
2013 & 216 & 420.4 & 585.4 & 247.5 & 214.9 & 244.9 & 194.9 & 211 & 235 & 322 & 575 & 568 \\
2014 & 262 & 442 & 81 & 456 & 233 & 257 & 184 & 469 & 379 & 366 & 426 & 615 \\
2015 & 291 & 200 & 233 & 487 & 398 & 224 & 169 & 326 & 324 & 464 & 653 & 217 \\
2016 & 160 & 216 & 293 & 385 & 98 & 457 & 112 & 422 & 353 & 140 & 517 & 395 \\
2017 & 264 & 338 & 750 & 481 & 447 & 627 & 144 & 366 & 374 & 509 & 296 & 458 \\
2018 & 364 & 182 & 197 & 266 & 681 & 112 & 295 & 535 & 565 & 290 & 769 & 405 \\
2019 & 162 & 385 & 365 & 261 & 400 & 215 & 177 & 189 & 343 & 562 & 521 & 300 \\
\hline
\end{tabular}

Formula the Simple Moving Acarage is as follows:

Where :

$$
F_{t+1}=\left(Y_{t}+Y_{t+1}+Y_{t+2}+\cdots+Y_{t+n+1}\right) / n
$$

$F_{t}=$ forecast value for next period

$Y_{t}=$ actual value at period $t$

$n=$ Limit number of the moving average

Calculations with $n=8$ and the data on the month of January

$$
\begin{aligned}
& F_{8}=\frac{264.8+156+216+262+291+160+264+364}{8} \\
& F_{8}=247 \\
& F_{9}=\frac{156+216+262+291+160+264+364+162}{8} \\
& F_{9}=234
\end{aligned}
$$

The forecasting results then obtained data of rainfall prediction for the year $2020\left(F_{9}\right)$ which will then be rounded to integers, which can be seen in the table below :

Table 2. Results Of The Prediction Of The Year 2020

Year Banyaknya Curah Hujan $\left(\mathrm{mm}^{3}\right)$




\begin{tabular}{cccccccccccccc}
\hline & Jan & Feb & Mar & Apr & Mei & Jun & Jul & Agus & Sept & Okt & Nov & Des \\
\hline$F_{8}$ & 247 & 308 & 397 & 360 & 303 & 336 & 209 & 344 & 379 & 366 & 589 & 399 \\
$F_{9}(2020)$ & 234 & 303 & 340 & 364 & 318 & 320 & 184 & 329 & 355 & 361 & 582 & 411 \\
\hline
\end{tabular}

\section{Conclusion}

After doing research on the application of the method of the Simple Moving Average (SMA) for the analysis of the level of vulnerability to flood in Padang city, it can take some conclusions as follows

1. This research successfully apply the method of Simple Moving Average (SMA) to predict the amount of rainfall the city of padang from the years 2011-2019.

2. Based on the analysis of the parameters of precipitation, it was found that the amount of rainfall $\left(\mathrm{mm}^{3}\right)$ predicted in November 2020 with a value of $582 \mathrm{~mm}^{3}$

\section{Referensi}

[1] Abbas. Irfan, "Penerapan Metode Moving Average (MA) Berbasis Algoritma Support Vector Machine (SVM) Untuk Membandingkan Pola Kurva Dengan Trend Kurva Pada Tradding Forex Online", ILKOM Jurnal Ilmiah, vol 8, no 1, 37-43, 2016.

[2] Agustian. Surya, Wibowo. Heru,.”Perbandingan Metode Moving Average Untuk Prediksi Hasil Produksi Kelapa Sawit" Seminar Nasional Teknologi Informasi, Komunikasi dan Industri (SNTIKI) 11, Hal. 156-162.

[3] Kushaeri. Ahmad, dkk., "Algoritma C.45 Untuk Pemodelan Daerah Rawan Banjir Studi Kasus Kabupaten Karawang Jawa Barat”, ILKOM Jurnal Ilmiah, vol 9, nomor 2, 132-136, 2017.

[4] Larasanti. Z. Rahma, Hariyanto. Teguh, Kurniawan. Akbar, "Pemetaan Daerah Risiko Banjir Lahar Berbasis SIG Untuk Menunjang Kegiatan Mitigasi Bencana (Studi Kasus : Gunung Semeru, Kab. Lumajang)", Jurnal Teknik ITS, vol 6, no 2, C363-C368, 2017.

[5] Setiawan. Yudi, dkk, "Pemetaan Zonasi Rawan Banjir Dengan Analisa Indeks Rawan Banjir Menggunakan Metode Fuzzy Simple Adaptive Weighting”, Jurnal Pseudocode, vol 7, no 1, 78-87, 2020.

[6] Suherianti, Mayub. A, Farid. M, "Potensi Rawan Banjir Kecamatan Bangkahulu Sebagai Penunjang Pembelajaran Materi Pemanasan Global Di SMPN 11 Kota Bengkulu", PENDIPA Journal of Science Education, vol 2, no 1, 95-102, 2018

[7] Hadi, A. F. (2017). Analisis Data Mining Untuk Menentukan Variabel-Variabel Yang Mempengaruhi Kelayakan Kredit Kepemilikan Rumah Menggunakan Teknik Klasifikasi. Komputer Teknologi Informasi, 4(1). 